\title{
THE OCCURRENCE OF Ganoderma SPORES IN THE AIR AND ITS RELATIONSHIPS WITH METEOROLOGICAL FACTORS
}

\author{
Agnieszka Grinn-Gofroń \\ Department of Plant Taxonomy and Phytogeography, University of Szczecin, \\ Wąska 13, 71-415 Szczecin, Poland \\ e-mail: agofr@univ.szczecin.pl
}

Received: 5.02.2010

\begin{abstract}
:
According to a recent study, Ganoderma may be the third genus, after Alternaria and Cladosporium, whose spores cause symptoms of allergy and whose levels are directly related to meteorological factors. There are only few articles from different parts of the world about the relationships between $\mathrm{Ga}$ noderma spore count and meteorological factors. The aim of the study was to review all available publications about airborne Ganoderma spores and to compare the results in a short useful form.
\end{abstract}

Key words: Ganoderma, airborne spores, meteorological factors, statistical correlation

\section{INTRODUCTION}

Airborne spores are the primary means of dispersal for fungi. Spores are single or multicellular units surrounded by a rigid (usually chitinous) cell wall. Each spore is capable of reproducing the entire organism (as opposed to pollen grains, which only carry half of the genetic complement of the plant). Fungi can have very complex life cycles, sometimes with up to five morphologically distinct spore types produced during a single cycle. This makes the classification of fungal sources based on airborne spores rather difficult.

Most commonly isolated and identified from air samples are spores of the two largest fungal groups: the Ascomycota and the Basidiomycota. The last group includes mushrooms, puffballs, and bracket fungi, the largest and most conspicuous fungi in the environment. Also included are the rusts and smuts (two groups of plant pathogens that lack fruiting bodies) as well as some yeasts. The characteristic sexual spore in the basidiomycetes (the common name for members of this division) is the basidiospore, which is externally formed on a basidium. Each basidium typically bears four spores on peglike appendages. Karyogamy and meiosis occur within the basidium, and the four haploid products of meiosis give rise to the four basidiospores. Basidia line the gills of mushrooms and the pores of bracket fungi, with the resulting basidiospores exposed to the atmosphere throughout development. Except for the rusts and smuts, basidiospores are the primary means of dispersal for the Basidiomycetes. Basidiospores are always single-celled, and most have an asymmetrically placed attachment peg (the attachment point to the sterigmata of the basidium). Color, size, and shape of basidiospores vary within relatively narrow ranges. The colors range from nearly black to colourless, with yellow, gold and brown pigments prominent. Sizes range from about 2 to $25 \mu \mathrm{m}$, with many spores in the 5 to $10 \mu \mathrm{m}$ range. Shapes are most often ovate, with occasional species producing elongated, angular, nodulose spores. Many basidiospores have a pore at the end opposite the attachment appendage.

The basisiospores of Ganoderma, commonly known as a bracket fungus or wood decay fungus, are an important and prevalent group of fungal air spora worldwide (Levetin, 1990, 1991; H a s n a in, 1993; Ha l wa gy, 1994; Le hre r et al. 1994; Li and Kendrick, 1995). At least six species of $G a$ noderma occur in Poland. Their polypores are found growing on dead or living hardwood and conifers. The spores have an orange inner wall and spines that penetrate a colourless outer wall, with a truncated end. This fungus is absolutely from outdoor sources. Ganoderma spores range in size from 6.5-13 x 5-9 micrometers.

Discharge of basidiospores, especially from bracket fungi, requires atmospheric moisture, although the mechanism in not completely understood. Basidiospores are frequently seen in the predawn hours when the humidity is high. However, Haard and Kramer 
(1970) investigated spore discharge in 19 species of mushrooms and bracket fungi and found three basic patterns. In many species, a night-time maximum was evident, with spore release increasing in the late afternoon or early evening, peaking during the middle of the night, and then decreasing in the morning. Other species, especially some bracket fungi, showed a double peak of spore release in the early morning and evening hours, while many small mushrooms showed continuous spore discharge with a peak 24 to $48 \mathrm{~h}$ after the onset of spore discharge and then a gradual decrease as the basidiocarp aged.

Gregory and Hirst (1952) first suggested that basidiospores might be associated with respiratory allergy. Studies from various parts of the world have clearly implicated Ganoderma spores as aeroallergens (T a rlo et al. 1979; Has n a in et al. 2004), and they have been implicated in the elicitation of respiratory allergic diseases (Cutten et al. 1988; S prenger et al. 1988).

Tarlo et al. (1979) found Ganoderma basidiospores to be the most prevalent fungal air spores in Ontario (Canada) and reported human sensitization to Ganoderma extracts. Hasnain et al. (1985), Cutten et al. (1988) and Hasnain (1993), in their studies from Auckland, New Zealand, reported that Ganoder$m a$ basidiospores constituted a major component of the air spora and were potential sources of allergens involved in asthma and allergic rhinitis. These authors also suggested that persistent exposure to Ganoderma basidiospores could stimulate a base level of allergic responsiveness in susceptible atopic patients. Positive skin and inhalation tests to Ganoderma applanatum have been reported by Her x he i mer et al. (1969). Lehrer et al. (1986) and Sprenger et al. (1988) found in their studies that $32 \%$ of atopic populations in New Orleans, Louisiana, and 30\% in Seattle, Washington, USA, were skin test positive to the basidiospores extracts including Ganoderma. Singh et al. (1994) reported sensitization to Ganoderma lucidum in the atopic population in India. Intradermal and skin prick tests performed using antigenic extract of $G$. lucidum revealed that $28.4 \%$, and $17.4 \%$ of patients showed marked skin reactivity to the spores and whole body extracts, respectively. Nonetheless, the airborne basidiospores have been ignored in many studies, yet high concentrations of basidiospores exist in the atmosphere at various locations around the world (G r e g o r y and Hirst, 1952; S a lvaggi o et al. 1971; Rubulis, 1984; Anderson, 1985; Hasnain et al. 1985; M is r a, 1987; L e veti n, 1990, 1991). In Sweden, basidiospores accounted for about $30 \%$ of the total air spora collected during a several-year study (Rubulis, 1984). In Arctic and subarctic areas, the air spora tends to be dominated by basidiospores and ascospores during the short spore-producing season (L a c e y , 1981;
Anders on, 1985). Fall peaks in the concentration of airborne basidiospores have been reported in some of these studies, while both late spring and fall peaks occur in Tulsa, Oklahoma. Previously, studies have categorized basidiospores as coloured and colourless or identified one or two distinctive genera; recent work has identified airborne basidiospores from 18 genera (Levet in, 1991).

\section{Presence in the air}

Ganoderma spores very often occur together with those of Cladosporium and Alternaria. Seasonally, spore levels of Ganoderma peaked toward summer and autumn. Tarlo et al. (1979) found Ganoderma basidiospores to be the most prevalent fungal air spores in Canada, while $\mathrm{H}$ a s $\mathrm{n}$ a in et al. (1985), Cutten et al. (1988), Hasnain (1993) in their studies from New Zealand reported that Ganoderma basidiospores constituted a major component of the air spora, probably reflecting the great forested area in this country, and the markedly higher concentrations occurred in summer and autumn, from December to April. Similar results were noted by Mitakakis and Quest (2001) in Melbourne (Australia) where Ganoderma spores accounted for approximately $2 \%$ of all identified taxa. The highest concentrations of Ganoderma spores which occurred from June to October were noted in Mexico (Calderon et al. 1995), Canada ( $\mathrm{Li}$ and Kendrick, 1995) and India (Chakrabotry et al. 2003). Oliveira et al. (2009), during three-year aerobiological monitoring in two areas of Portugal differing in the urbanization level, recorded higher airborne concentrations (including Ganoderma spores) in late summer and early autumn (September and October) and the lowest in the winter months (January and February). In Badajoz (Spain), the basidiospores, including inter alia Ganoderma, were present in the atmosphere mainly during autumn. The maximum concentrations were found in November, with the lowest values being found during summer (G o z n a lo et at. 1997).

During a five-year study period in India, two very distinct periods of spore concentration were found, the first one in March and the second one in October. The highest number of Ganoderma spores occurred in October, probably because of high mean air temperature and relative humidity, low rainfall level and different wind speeds $(0.8-4.2 \mathrm{~km} / \mathrm{h})$. In Kerala District, the presence of spores was not noted in January and February, whereas the highest concentration occurred in August. This was due to specific weather conditions (Ch a kraborty et al. 2003). During year-round air monitoring conducted in Santiago (Chile), the concentration of Ganoderma spores increased in November, while the highest values occurred in February and April (I b ane z Henriquez et al. 2001). In Saudi 
Arabia (Jizan City) high concentrations were noted in December and January with air mean temperature between 15 and $20^{\circ} \mathrm{C}$ and relative humidity about $70 \%$ (H a s $\mathrm{n}$ a i $\mathrm{n}$ et al. 2004). In Poland the highest concentrations occurred in July (Gri n n-Go froń, 2008) and August (K a s przy k et al. 2004; S tę pals ka and W o ł e k, 2005). In Rzeszów (Poland) Ganoderma was the taxon whose spore concentration peaks latest, i.e. in August and in the first days of September ( $\mathrm{K}$ a s przyk et al. 2004).

In their results of a 10-year study on Ganoderma aerobiology, Craig and Le vet in (2000) reported, in addition to yearly fluctuations, that hourly concentrations also differ throughout the day. Its spore release follows a diurnal rhythm with a peak concentration at approximately 04:00 hours and lowest levels at 16:00 hours. A similar early morning maximum was observed by $\mathrm{H}$ a a r d and $\mathrm{Kr}$ a mer (1970) at 06:00 hours. Different results were obtained in Madras (India) by Vittal and Krishnamoorthi (1981). Ganoderma spores exhibited a peak concentration between midnight and dawn and were less common in the day time. It was noticed that there was a sudden increase in the numbers of spores from midnight onwards reaching a peak at 02:00 a.m. and then onwards there was a gradual decline till 18:00 hours after.

L a c e y (1981) observed that concentrations of airborne basidiospores of all types showed a diurnal periodicity typical of this fungal spore type, with the maximum concentration at night, between 02:00 and 04:00 h, when dew is sufficient for spore liberation.

\section{Correlations with meteorological factors}

\section{Minimum temperature}

A strong, statistically significant correlation between Ganoderma spore concentration and minimum temperature was noted only in the western and southern parts of Poland (Grin n-G of roń, 2008; Stępalska and Wołek, 2005). Both results can be considered reliable, because they were obtained by the same methodology and using the same statistical analysis - multiple regression.

\section{Mean temperature}

A positive, significant relationship between Ganoderma spores and average temperature was noted in Tulsa (Oklahoma, USA) (C r a ig and L e ve t i n , 2000), and in two cities of Portugal (P o r to and A mares) (Oliveira et al. 2009). Similar studies were carried out in Saudi Arabia and significant correlations for basidiospores were found only in Jizan, a small town close to the Red Sea. This town borders Yemen, which has a different flora and fauna with forested ranges, providing a possible source area for Jizan. High concentrations occurred in December and
January when temperatures are generally in the range $15-20^{\circ} \mathrm{C}$.

Calderon et al. (1995) noted a negative correlation between temperature and basidiospore count and suggested that spore production or fungal growth decreased at higher temperatures (about $>26^{\circ} \mathrm{C}$ ).

\section{Relative humidity}

In Mexico City Cald e ro n et al. (1995) observed the largest concentrations of basidiospores when relative humidity was 70 to $80 \%$. In their study, the concentrations of airborne basidiospores were directly correlated with $\mathrm{RH}$. It is well known that high humidity and rain favor the production and liberation of basidiospores. This compares with the reports of M c Cracken (1987) and Has nain et al. (2004) that the level of humidity about $70 \%$ was associated with increased concentrations of Ganoderma spores.

Examining the correlation between spores and meteorological factors in two cities of Portugal, Oli v e ir a et al. (2009) noted a similar positive correlation for Ganoderma spores. In Poland (Cracow) only S tę palsk a and W ołe k (2005) observed a positive significant relationship between Ganoderma spore count and relative humidity. The results were obtained by the multiple regression method and occurred only in the pre-peak period.

\section{Rainfall}

Hasnain (1993) in Auckland, Craig and Levetin (2000) in Tulsa and Calderon et al. (1995) in Mexico noted a significant correlation with precipitation. Ganoderma is considered to be a moist-air spore type because its concentrations showed marked seasonal differences with the highest numbers during the wet season and water is an important factor involved in spore release. Lace y (1990) observed abundance of basidiospores during the rainy period in tropical countries. The rainy season accelerates the development of sporocarps and release of more spores because of high humidity and water availability. A significant negative correlation with precipitation was noted in Poland both in Szczecin and Cracow (Gri in nGofroń, 2008; S tęp a lska and W ołek, 2005). In Szczecin the correlation was significant for two of the three seasons analyzed and in Cracow in the 1997 season. Both correlations were calculated using the same method (multiple regression).

\section{Wind speed}

Hasnain (1993) and Calderon et al. (1995) reported that large concentrations of basidiospores were often associated with daily average wind speeds of 2 to $3 \mathrm{~m} \mathrm{~s}^{-1}$. This compares with the reports of Lopez and Salvaggio (1983) and Hasnain (1993), among others, that wind velocities $>5 \mathrm{~m} \mathrm{~s}^{-1}$ 
were correlated with decreased concentrations, perhaps because of the diluting effect of high wind speeds on concentrations of airborne particles. In addition, increasing wind speed would also increase water loss and may, in turn, suppress spore production.

\section{Pressure}

A positive significant, but not so strong, correlation with air pressure was noted only in Szczecin by Gri in n- G o fr o ń (2008) during one season studied.

\section{Statistical models}

The only one statistical model for Ganoderma basidiospores in the air and its relationship to meteorological parameters using both the multivariate regression tree method (MRT) and classification artificial neural network (ANN) model were created in Poland (Grinn-Gofroń and Strzelczak, in press).

MRT analysis revealed that the presence or absence of Ganoderma spores depends mostly on dew point temperature, with the threshold value at the level of around $9^{\circ} \mathrm{C}$. Similar results were obtained in neural network modelling. The sensitivity analysis of ANN model classification showed that the most important factors determining Ganoderma presence/absence were dew point temperature and humidity with the cut-off value for the first variable equal to about $11^{\circ} \mathrm{C}$. Maximum and average wind speed and precipitation were less important, but still significant. No other author noted a correlation between dew point temperature and Ganoderma concentrations.

Based on the statistical models described above, the general conclusion is that very low performance of the regression models for the seasons suggests that there are some other variables influencing Ganoderma spore concentrations, more important than meteorological factors.

The presence of Ganoderma basidiospores within the air spora of the world and the high concentrations may be important for understanding allergic reactions. Aerobiological investigations should contribute to the understanding of allergic manifestations caused by basidiospores of Ganoderma.

\section{CONCLUSIONS}

- Ganoderma spores are noted in the air together with those of Alternaria and Cladosporium mostly during summer and early autumn.

- Minimum, mean temperature, and relative humidity were positively and statistically significantly correlated with Ganoderma spore concentration.

- An unclear situation occurred in the case of rainfall. Some authors noted a positive correlation, while others a negative one. In several cases, a statistically significant correlation did not occur.
- A positive significant correlation was reported also for average wind speed, but only in the range between 2 to $3 \mathrm{~m} \mathrm{~s}-1$.

- Dew point temperature was the most important factor in the statistical predictive models.

- Such discrepancies in the results of various studies suggest that, in addition to meteorological parameters, there are still other factors which strongly influence Ganoderma spore concentration in the air.

\section{REFERENCES}

Anders on J. H., 1985. Allergenic airborne pollen and spores in Anchorage, Alaska. Ann. Allergy, 54; 390.

Calderon C., Lacey J., McCartney A., Rosas I., 1995. Influence of urban climate upon distribution of airborne Deuteromycetes spore concentrations in Mexico City. Int. J. Biometeorol. 40; 71-80.

Chakrabotry P., Gupta-Bhattacharya S., Chand a S., 2003. Aeromycoflora of an agricultural farm in West Bengal, India: A five-year study (1994-1999). Grana, 42; 248-254.

Craig R. L., Levetin E., 2000. Multi-year study of Ganoderma aerobiology. Aerobiologia, 16; 75-80.

Cutten A. E. C., Hasnain S. M., Bai T. R., Mckay E. J., 1988. The basidiomycete Ganoderma and asthma; Collection, quantitation and immunogenicity of the spores. N. Zeal. Med. J. 101; 361-363.

Gonzalo M., Paredes M., Muńoz A., Tormo R., Silva I., 1997. Dinámica de dispersion de basidiosporas en la atmósfera de Badajoz. Rev. Esp. Alergol. Immunol. Clin. 12; 294-300.

Gregory P. H., Hirst J. M., 1952. Possible role of basidiospores as airborne allergens. Nature, 170: 414.

Grinn-Gofroń A., 2008. The variation in spore concentrations of selected fungal taxa associated with weather conditions in Szczecin, Poland, 2004-2006. Grana, 47 (2): 139-146.

Grinn-Gofroń A., Strzelaczak A., The effects of meteorological factors on the occurrence of Ganoderma sp. spores in the air. Int. J. Biometeorol. (in press).

Ha ard R. T., Kramer C. I., 1970. Periodicity of spore discharge in the Hymenomycetes. Mycologia, 62; 1145 1169.

Halwagy M. H., 1994. Fungal airspora of Kuwait city. Kuwait. Grana, 33: 340-345.

Has na in S. M., 1993. Influence of meteorological factors on the airspora. Grana 32: 184-188.

Hasnain S. M., Wilson J. D., Newhook F. J., 1985. Allergy to basidiospores: Immunologic studies. N. Zeal. Med. J. 98; 393-396.

Hasnain S. M., Al-Frayth A., Khatija F., Al-Sed a iry S., 2004. Airborne Ganoderma basidiospores in a country with desert environment. Grana, 43: 111-115.

Herxheimer H., Hyde H. A., Williams D. A., 1969. Allergic asthma caused by basidiospores. Lancet, 11; 131-133. 
Ibánez Henríquez V., Rojas Villegas G., Roure Nolla J. M., 2001. Airborne fungi monitoring in Santiago, Chile. Aerobiologia, 17: 137-142.

Kasprzyk I., Rzepowska B., Wasylów M., 2004. Fungal spores in the atmosphere of Rzeszów (SouthEast Poland). Ann. Agric. Environ. Med. 11: 285-289.

Lacey J., 1981. Aerobiology and health: the role of airborne fungal spores in respiratory allergy diseases, [In:] D.L. Hawksworth, (ed.), Frontiers in Mycology. 131156 , CBA, Wallingford.

La cey J., 1990. Aerobiology and health; the role of airborne fungal spores in respiratory diseases. [In:] D. L. Hawksworth (ed.), Frontiers in Mycology. CBA, Wallingford: 131-156.

Lopez M., Salvaggio E. J., 1983. Climate-WeatherAir Pollution, [In:] E. Middleton, C.E. Reed, E.F. Ellis, (eds), Allergy: Principle and practice. $1203-1214,2^{\text {nd }} . C$ V Mosby, St. Luis.

Lehrer S. B., Lopez M., Butcher B. T., Olsen J., Reed M., Salvaggio J. E., 1986. Basidiomycete mycelia and spore allergen extracts: skin reactivity in adults with symptoms of respiratory allergy. $\mathrm{J}$. Allergy Clin. Immunol. 78: 478-485.

Lehrer S. B., Hughes J. M., Altman L. C., Bousquet J., Davies R. J., Gell Li J., Lopez M., Malling H. J., Mathison D. A., Sastre J., Schultze-Werninghaus G., Schwartz H. J., 1994. Prevalence of basidiomycete allergy in the USA and Europe and its relatuionship to allergic respiratory symptoms. Allergy, 49: 460-465.

Levetin E., 1990. Studies on airborne basidiospores. Aerobiologia, 6: 177-180.

Levetin E., 1991. Identification and concentration of airborne basidiospores. Grana, 30: 123-128.

Li D. W., Kendrick B., 1995. A year-round outdoor aeromycological study in Waterloo, Ontario, Canada. Grana, 34: 199-207.

McCracken F. L., 1987. Factors affecting the spore release of Ganoderma applanatus. J. MI Academic Science, 32: 55-60.

Misra R. P., 1987. Studies on seasonal and diurnal variation in the occurrence of airborne spores of basidiomycetes. Perspect. Mycol. Res. 1: 243.

Mitakakis T. Z., Guest D. I., 2001. A fungal spore calendar for the atmosphere of Melbourne, Australia, for the year 1993. Aerobiologia, 17: 171-176.

Oliveira M., Ribeiro H., Abreu I., 2009. Annual variation of fungal spores in atmosphere of Porto: 2003. Annals Agric. Envir. Med., 12: 309-315.

Rubulis J., 1984. Airborne fungal spores in Stocholm and Eskilstuna, central Sweden. Nordic Aerobiol. 85.

Salvaggio J., Seabury J., Schoenhardt E. A., 1971. New Orleans asthma. V. Relationshop between Charity hospital asthma admissions rates, semiquantitative pollen and fungal spore counts, and total particulate sampling data. J. Allergy Clin. Immunol. 48; 96.
Singh A. B., Gupta S. K., Pereira B. M. J., Prakas h D., 1994. Sensitization to Ganoderma lucidum in patients with respiratory allergy in India. Clinical and Experimental Allergy, 25: 440-447.

Sprenger J. D., Altman L. C., O'Neil C. E., 1988. Prevalence of basidiospores allergy in the pacific Northwest. J. Allergy Clin. Immunol. 82; 1076-1080.

Stępalska D., Wołek J., 2005. Variation in fungal spore concentrations of selected taxa associated to weather conditions in Cracow, Poland, in 1997. Aerobiologia, 21: 43-52.

Tarlo S. M., Bell B., Srinivasan Dolovich J., Hargreave F. E., 1979. Human sensitization to Ganoderma antigen. Journal of Allergy and Clinical Immunology, 64: 43-49.

Vittal B. P. R., Krishnamoorthi K., 1981. Air spora of an agricultural farm in Madras, India. Grana, 20: 61-64.

\section{Występowanie zarodników Ganoderma w powietrzu i korelacje z czynnikami pogodowymi}

\section{Streszczenie}

Rodzaj Ganoderma jest trzecim po Alternaria i Cladosporium rodzajem grzybów wywołującym objawy alergii. Niestety nie opracowano dotąd wartości stężeń progowych dla tych zarodników, a liczba publikacji opisujących związek stężenia zarodników z czynnikami meteorologicznymi jest wciąż mała.

Najwyższe koncentracje zarodników tego rodzaju notowane są w okresie późnego lata, wczesnej jesieni i w porównaniu z innymi typami stanowią jedną z bardziej licznych grup. Statystycznie istotne, pozytywne korelacje były notowane dla dobowych średnich i minimalnych temperatur oraz dla wilgotności względnej a negatywne dla: wysokości opadów deszczu ale tylko w kilku przypadkach. Średnia prędkość wiatru w zakresie od 2 do $3 \mathrm{~m} / \mathrm{s}$ również była pozytywnie skorelowana z liczbą zarodników w powietrzu. Wyższe i niższe prędkości wiatru nie wykazywały statystycznie istotnych korelacji.

Statystyczny model prognostyczny oparty na wieloregresyjnym drzewie neuronowym i sztucznych sieciach neuronowych za najważniejszy czynnik warunkujący wysokie stężenie zarodników Ganoderma w powietrzu uznał temperaturę punktu rosy.

Rozbieżności w wynikach mogą sugerować, że oprócz parametrów meteorologicznych istnieją inne czynniki, które w znaczący sposób wpływają na obecność zarodników Ganoderma w powietrzu. 
